\title{
PENTINGNYA ASPEK HUKUM PELESTARIAN DANAU LIMBOTO DAN PEMANFAATAN ECENG GONDOK SEBAGAI PRODUK KERAJINAN TANGAN KHAS MASYARAKAT DESA BUHU KABUPATEN GORONTALO
}

\author{
Weny Almoravid Dungga ${ }^{1 *}$, Ismet Sulila², Yanti Aneta ${ }^{2}$ \\ 1*Program Studi Ilmu Hukum, Fakultas Hukum, Universitas Negeri Gorontalo, Gorontalo, Indonesia \\ ${ }_{2}^{2}$ Program Studi Administrasi Publik, Fakultas Ekonomi, Universitas Negeri Gorontalo, Gorontalo, Indonesia \\ *Penulis Korespondensi: wenydungga@gmail.com
}

\begin{abstract}
Abstrak
Pelestarian lingkungan danau limboto menjadi kewajiban dan tanggungjawab bersama untuk menjamin keberlanjutan ekosistem, oleh karenanya dibutuhkan partisipasi aktif dari kelompok masyarakat. Untuk mewujudkan maksud tersebut maka Pemerintah Provinsi Gorontalo telah menetapkan Peraturan Daerah Nomor 1 Tahun 2008 tentang pengelolaan danau Limboto. Kebijakan ini tentu membutuhkan dukungan konkrit masyarakat. Salah satu desa yang terletak dipesisir danau Limboto adalah desa Buhu. Desa ini sering berhadapan dengan masalah banjir pada musim penghujan dan juga masalah serius pendangkalan danau Limboto sebagai akibat dari cepatnya pertumbuhan eceng gondok. Mata pencaharian masyarakat dikampung ini bervariasi, mulai dari nelayan, serabutan dan pengrajin. Untuk menindaklanjuti masalah pokok dimaksud maka bentuk kegiatan yang dilaksanakan adalah : 1) sosialisasi hukum perlindungan lingkungan danau Limboto, 2) bimbingan teknis manajemen bagi kelompok pengrajin eceng gondok. Adapun metode yang digunakan untuk menyelesaikan masalah dimaksud adalah diskusi komprehensif dan mendasar, teori dan pendampingan praktek manajemen kerajinan tangan anyaman eceng gondok oleh tim ahli/pakar bersama mahasiswa dan kelompok sasaran. Hasil kegiatan yang dicapai adalah: 1) adanya kesadaran masyarakat setempat terhadap pentingnya pelestarian lingkungan danau Limboto, 2) meningkatnya kapasitas manajemen kelompok pengrajin anyaman eceng gondok.
\end{abstract}

Kata kunci: Pelestarian lingkungan, pemberdayaan dan standarisasi produk

\begin{abstract}
Stakeholders, such as people or group of community, are responsible for environmental conservation of Limboto lake; this is also to ensure a sustainable ecosystem. The government of Gorontalo Province has constituted the Regional Regulation No. 1 of 2008 considering the management of Limboto lake to achieve such a target. This policy requires support from the community. Buhu village is among the villages based in the coastal lakes of Limboto lake. The village always suffers from flood strikes the village during rainy season. On top of that, the issue of silting is also one of the major concern in Limboto lake due to the growth of common water hyacinth (Eceng Gondok). The villagers have different occupations, e.g., fishermen and artisans. In responding to the previous concerns, the implementation of the program consists of steps, such as 1) improving people's understanding regarding the protection of the environment surrounding Limboto lake through seminars, and 2) conducting workshops for water hyacinth artisans. Comprehensive and fundamental discussion was used as the method to address the issues. Furthermore, experts along with university students conducted workshops on management practice for the artisans. The results are 1) the rise in people's awareness about the importance of the preservation of Limboto lake, and 2) reinforcing the management capacity of the water hyacinth artisans.
\end{abstract}

Keywords: Environmental Preservation, Empowerment and Product Standardization

\section{PENDAHULUAN}

Peraturan Daerah Nomor 1 Tahun 2008 pengelolaan danau Limboto ditetapkan oleh Pemerintah Kabupaten Gorontalo dengan tujuan : 1) mencegah kerusakan dan merehabilitasi danau; memanfaatkan danau untuk kepentingan masyarakat secara berkelanjutan dan ramah lingkungan; serta melestarikan fungsi-fungsi danau; 2) mewujudkan keterpaduan dan mengembangkan kerjasama pengelolaan danau; 3) meningkatkan pengetahuan dan keterampilan, kemandirian dan partisipasi masyarakat dalam pengelolaan danau; 4) mempertahankan fungsi Danau Limboto dan DAS Limboto sebagai komponen kelestarian lingkungan hidup, pengendali banjir, 
sumberdaya perikanan, obyek wisata dan rekreasi, sarana transportasi, tempat pendidikan dan penelitian. Salah satu desa yang terletak dikawasan pesisir danau Limboto adalah desa Buhu. Desa ini merupakan desa dengan masyarakat tingkat ekonomi menengah ke bawah yang sebagian besar mata pencahariannya bergantung pada danau Limboto Kabupaten Gorontalo. Secara geografis desa Buhu berdampingan pada sisi bagian barat adalah danau Limboto, sisi bagian timur bersebelahan dengan desa Tenggela dan sisi bagian utara berbatasan dengan desa Buliide. Desa Buhu memiliki luas wilayah kurang lebih $120 \mathrm{Ha}$ terdiri atas 3 wilayah dusun, dengan jumlah penduduk 2.155 jiwa. Sebagian besar masyarakat memenuhi kebutuhan hidup dengan cara mengandalkan sumber daya danau yaitu perikanan. Perikanan yang paling banyak dijalani oleh warga adalah budidaya ikan melalui keramba/jaring sehingga masyarakat di desa ini juga dikenal sebagai salah satu sumber perikanan danau di wilayah Gorontalo. Namun disisi lain penghasilan yang diperoleh dari profesi sebagai nelayan belumlah cukup untuk memenuhi kebutuhan hidup anggota keluarga. Disamping itu pula dalam melaksanakan usaha jaring ikan masalah yang dihadapi masyarakat nelayan adalah banyaknya tumbuhan eceng gondok di wilayah danau Limboto yang dirasakan cukup mengganggu perkembangan budidaya ikan yang dilaksanakan masyarakat. Sesungguhnya terdapat tiga upaya pokok dalam pemberdayaan masyarakat, yaitu bina manusia, bina usaha dan bina lingkungan. Terhadap ketiga rumusan di atas hanya akan terwujud seperti yang diharapkan manakala didukung oleh efektifitas beragam kelembagaan yang diperlukan (Mardikanto, 2003).

Eceng gondok yang memiliki nama ilmiah Eichornia crassipes merupakan tumbuhan air dan lebih sering dianggap sebagai tumbuhan pengganggu perairan. Eceng gondok memiliki tingkat pertumbuhan yang sangat cepat. Dalam tempo 3 s.d 4 bulan saja, eceng gondok mampu menutupi lebih dari $70 \%$ permukaan danau. Cepatnya pertumbuhan eceng gondok dan tingginya daya tahan hidup menjadikan tumbuhan ini sangat sulit diberantas. Pada beberapa negara, pemberantasan eceng gondok secara mekanik, kimia dan biologi tidak pernah memberikan hasil yang optimal. Beberapa hasil penelitian juga menunjukkan bahwa eceng gondok berpotensi menghilangkan air permukaan sampai 4 kali lipat jika dibandingkan dengan permukaan terbuka. Pertumbuhan populasi eceng gondok yang tidak terkendali menyebabkan pendangkalan ekosistem perairan dan tertutupnya sungai serta danau, dimana hal ini sebagaimana terlihat sangat nyata di danau Limboto kabupaten Gorontalo.

Pemerintah Kabupaten Gorontalo telah menetapkan Desa Buhu sebagai salah satu wilayah strategis pengembangan kerajinan anyaman dengan bahan dasar eceng gondok. Hal ini akan berdampak pada : 1) Upaya nyata pelestarian lingkungan danau limboto melalui pembersihan dan pengangkatan eceng gondok sebagai salah satu penyebab utama pendangkalan, 2) Upaya nyata pemanfaatan eceng gondok menjadi ragam produk kerajinan dengan ciri khas desa Buhu. Upaya pemanfaatan eceng gondok dilakukan untuk memperkenalkan beberapa potensi produk yang dihasilkan melalui anyaman eceng gondok dengan desain beberapa produk bahan dasar eceng gondok. Diantara beberapa produk yang bisa dihasilkan melalui bahan dasar eceng gondok adalah kursi stelan untuk ruang tamu, meja, kursi hias, keranjang, bingkai kaca, tas dan produk kerajinan lainnya. Produk Anyaman kerajinan tangan berbahan dasar eceng gondok memiliki jenis/ragam produk yang biasanya digunakan untuk memenuhhi kebutuhan baik perorangan maupun kebutuhan kelompok rumah tangga. Adapun diantara jenisnya dapat dirinci sebagai berikut :

Tabel 1. Ragam Jenis Produk Eceng Gondok

\begin{tabular}{|c|l|l|}
\hline No & $\begin{array}{c}\text { Jenis Produk Anyaman } \\
\text { Berbahan Eceng Gondok }\end{array}$ & $\begin{array}{c}\text { Keterangan } \\
\text { Produk }\end{array}$ \\
\hline 1 & Anyaman setelan kursi & Produk Utama \\
\hline 2 & Anyaman partisi/pembatas & Produk Utama \\
\hline 3 & Anyaman meja kerja & Produk Utama \\
\hline 4 & Anyaman tas belanja & Produk Turunan \\
\hline 5 & Anyaman sandal & Produk Turunan \\
\hline 6 & Anyaman box penyimpanan & Produk Turunan \\
\hline
\end{tabular}

Sumber : Identifikasi Lapangan 2018

Adapun potensi unggulan dan masalah yang dihadapi kelompok masyarakat akan dijabarkan secara rinci sebagai berikut: 1) Potensi Unggulan : a) Melimpahnya bahan baku eceng gondok di pesisir danau Limboto, b) Kemampuan kelompok masyarakat dalam menghadirkan keunikan dan ciri khas produk anyaman eceng gondok Desa Buhu dengan beragam produk, c) Masih tingginya permintaan produk anyaman eceng gondok dengan standarisasi kualitas untuk memenuhi kebutuhan rumah tangga di kawasan Gorontalo dan sekitarnya, d) Kemauan dan kesungguhan kelompok masyarakat dalam pemanfaatan eceng gondok untuk memenuhi kebutuhan pasar, e) Dukungan pemerintah setempat, Dinas/Instansi terkait dan program penguatan/pengembangan usaha dengan pinjaman tanpa bunga. 2) Masalah yang dihadapi: a) Belum ada arah yang jelas tentang manajemen tata kelola pemanfaatan eceng gondok, b) Tidak maksimalnya praktek fungsi manajemen dan SDM pengembangan usaha kelompok yang berkelanjutan dan dibutuhkan bimbingan teknis aspek keuangan, produksi, pemasaran dan aspek penting lainnya, c) Belum adanya standarisasi kualitas aneka produk anyaman eceng gondok sesuai permintaan pasar/mitra. Dibutuhkan bimbingan teknis standarisasi mutu produk, d) Masih minimnya pengetahuan dan keterampilan manajemen, standarisasi produk, tata kelola keuangan dan strategi pemasaran kompetitif, e) Kurang efektifnya aspek kelembagaan kelompok, struktur dan kekompakan tim sehingga membuka peluang pembinaan dan pengembangan stakeholders secara berkelanjutan. 
Berbagai potensi di atas masih perlu untuk terus dikembangkan dengan berfokus pada dua aspek utama yaitu aspek hukum dan aspek manajemen. Berdasarkan potensi dan masalah yang dihadapi oleh kelompok sasaran sebagaimana dijelaskan di atas, maka tim pelaksana program KKN PPM tahun 2018 telah melaksanakan observasi dan penyusunan program dengan kelompok sasaran desa Buhu untuk berpartisipasi aktif dalam kegiatan. Oleh karena itu fokus kegiatan intervensi ilmu pengetahuan dan teknologi oleh tim pelaksana KKN PPM terhadap kelompok sasaran dirinci sebagai berikut :

1) Sosialisasi program yang difokuskan pada pentingnya aspek hukum dalam pelestarian lingkungan alam pesisir danau limboto.

2) Membangun partisipasi aktif masyarakat desa pesisir danau limboto untuk berperan serta secara aktif dalam kegiatan pelestarian danau limboto.

3) Melaksanakan bimbingan teknis manajemen pembuatan ragam kerajinan tangan berbahan dasar eceng gondok bagi masyarakat desa Buhu pesisir danau limboto sebagai kelompok sasaran.

4) Monitoring dan evaluasi tingkat keberhasilan program dan tindaklanjut perbaikan hasil kegiatan untuk menjamin keberlangsungan program pada masa yang akan datang.

\section{BAHAN DAN METODE}

Berdasarkan uraian pada pendahuluan di atas maka dibutuhkan dasar kebijakan yang digunakan dalam tema kegiatan ini, yaitu Perda Nomor 1 Tahun 2008 tentang pengelolaan danau limboto sebagai materi kegiatan sosialisasi dan acuan bagi seluruh masyarakat pesisir dalam pelestarian dan explorasi danau serta pemanfaatan eceng gondok. Bahan selanjutnya yaitu eceng gondok yang berasal dari danau limboto yang diproses melalui tahapan yang telah ditetapkan. Sedangkan metode yang digunakan yaitu dimulai dari metode observasi partisipatif terhadap objek dimana tim pelaksana mempersiapkan secara matang dan terlibat langsung dalam setiap langkah kerjanya. Metode yang digunakan untuk program sosialisasi hukum adalah ceramah, diskusi dan tanya jawab. Pemilihan metode tersebut didasarkan pada pencapaian target yang telah ditetapkan. Adapun jumlah masyarakat yang mengikuti seluruh rangkaian kegiatan ini adalah 40 (empat puluh) orang, dengan target adanya pemahaman dan partisipasi aktif masyarakat pesisir danau limboto dan sekitarnya terhadap pentingnya aspek hukum dan perlindungannya dalam pemanfaatan serta pelestarian danau yang berkelanjutan. Sedangkan metode yang digunakan untuk program ekonomi dan manajemen adalah melakukan pemberdayaan kelompok sasaran dengan teknik pembelajaran kelompok disertai praktek, teknik pengangkatan eceng gondok dari danau limboto, pemilihan bahan yang berkualitas, penjemuran, pemanfaatan menjadi produk anyaman, pengecatan, penetapan harga produksi, harga jual sampai pada pemasaran produk. Menurut definisinya pemberdayaan diartikan sebagai upaya untuk memberikan daya (empowerment) atau penguatan (strengthening) kepada masyarakat (Mas'oed : 1993). Sedangkan keberdayaan masyarakat juga dipandang sebagai kemampuan individu yang bersenyawa dengan masyarakat dalam membangun keberdayaan masyarakat yang bersangkutan (Sumodiningrat : 1997). Selanjutnya dalam hal pekerjaan yang dilakukan oleh mahasiswa dihitung dalam volume 144 Jam Kerja Efektif Mahasiswa (JKEM) dalam sebulan. Rata-rata jam kerja efektif mahasiswa (JKEM) per hari adalah 4,8 sebagai acuan.

Sementara itu untuk menjamin kebermanfaatan program ini pada masa yang akan datang maka dibutuhkan upaya serius untuk keberlanjutan program. Keberlanjutan program akan ditentukan oleh komitmen kerja mahasiswa dalam pelaksanaan kegiatan KKN-PPM yang bekerjasama dengan karang taruna setempat sebagai pendamping keberlanjutan program. Penempatan mahasiswa pada semua program kegiatan adalah dalam rangka memetakan potensi dan masalah yang mungkin muncul serta solusi dan alternatifnya. Bantuan penerapan teknologi produksi serta pemasaran adalah upaya meningkatkan efisiensi dan efektifitas proses usaha kerajinan anyaman. Keberadaan bantuan ini akan meningkatkan kinerja produksi dan pengolahan serta standarisasi mutu anyaman eceng gondok yang dilakukan oleh kelompok sasaran.

\section{HASIL DAN PEMBAHASAN}

Berdasarkan implementasi program kuliah kerja nyata (KKN-PPM) tahun 2018 di desa Buhu Kecamatan Telaga Jaya Kabupaten Gorontalo, maka hasil dan pembahasannya diuraikan sebagai berikut: a) Materi Aspek Hukum: Kegiatan ini dilaksanakan dalam bentuk konkrit berupa sosialisasi kepada masyarakat pesisir tentang pentingnya aspek hukum dalam pelestarian danau limboto, serta perlindungan danau Limboto untuk kehidupan yang berkelanjutan. Kegiatan dan hasilnya diuraikan sebagai berikut : 1) Memberikan sosialisasi kepada masyarakat tentang pentingnya pelestarian danau Limboto. Hasilnya menunjukkan bahwa sebagian besar masyarakat pesisir mampu memahami keberadaan danau Limboto sebagai sumber penghidupannya yang perlu terus dijaga kelestariannya. Kegiatan ini selain dihadiri oleh kelompok sasaran, mahasiswa, tim pelaksana, juga dihadiri oleh pemerintah setempat. Hasil kegiatan sosialisasi ini selanjutnya akan dilihat penerapannya dalam kehidupan sehari-hari, yang ditandai dengan kebersamaan masyarakat dalam mengurangi pendangkalan danau yang dilaksanakan dengan aksi kebersihan pengangkatan eceng gondok dari permukaan danau. Bagi mahasiswa fokus kegiatan di atas memberikan manfaat akan pentingnya perbandingan antara konsep perlindungan hukum danau limboto dengan implementasinya oleh masyarakat dilapangan secara bersama-sama. Bagi tim dosen pelaksana memberikan manfaat tentang pentingnya upaya dan tindakan konkrit dalam bentuk pengabdian pada masyarakat sebagai salah satu bentuk tri dharma perguruan tinggi. 2) Sosialisasi aspek 
hukum dalam perlindungan danau Limboto juga memberikan jaminan kepada masyarakat untuk mengetahui batas-batas pengelolaan danau untuk kehidupannya. Demikian juga masyarakat akan mengetahui batasan kewajiban dalam upaya perlindungan danau Limboto yang berkelanjutan. Hasil kegiatan ini bagi mahasiswa memberikan manfaat pada pentingnya perlindungan lingkungan untuk kehidupan yang berkelanjutan bagi masyarakat. Sedangkan bagi tim dosen pelaksana hasil kegiatan sebagai bentuk kepedulian dalam melindungi sumber kehidupan masyarakat baik pada masa sekarang dan masa yang akan datang. 3) Dalam kaitannya dengan kegiatan bimbingan teknis manajemen maka terdapat peningkatan keterampilan kelompok sasaran dalam fokus penerapan teknologi produksi ragam produk anyaman kerajinan eceng gondok untuk menghasilkan kuantitas dan kualitas produk sesuai standar kebutuhan pasar. 4) Bertambahnya pemahaman dan pengetahuan kelompok pengrajin dalam menghasilkan ragam produksi kerajinan eceng gondok untuk meningkatkan kesejahteraannya. 5) Meningkatnya pemahaman dan kemampuan praktek kelompok sasaran dalam standarisasi produksi. 6) Bertambahnya jumlah kapasitas produksi ragam produk kerajinan eceng gondok sebagai akibat dari perbaikan manajemen kelompok secara bertahap dan terukur. 7) Hasil bimbingan teknis bagi mahasiswa memperoleh pengalaman empirik di lapangan tentang berbagai masalah mendasar yang dihadapi masyarakat sekaligus berupaya membuat analisis dan solusi konkrit dalam pemecahan masalah secara bertahap dan terukur. 8) Bagi pemerintah setempat dapat memberdayakan masyarakat kelompok pengrajin anyaman eceng gondok, meningkatkan produktivitas kelompok, sedikitnya mengurangi tingkat pengangguran dan menggerakkan ekonomi masyarakat setempat. Untuk menghasilkan kegiatan bimtek manajemen usaha kecil yang efektif maka materi bimbingan teknis disusun berdasarkan kebutuhan kelompok sasaran dengan rincian materi sebagai berikut:

1) Materi Pertama: Dasar-dasar manajemen bagi Usaha Mikro Kecil Menengah (UMKM). Materi ini dimulai dari pengungkapan berbagai potensi ril yang dimiliki desa salah satunya potensi produk anyaman dengan bahan baku eceng gondok yang banyak terdapat di wilayah ini. Materi dilanjutkan dengan teori dan praktek fungsi-fungsi manajemen dan unsur-unsur manajemen. Disamping itu pula diuraikan secara rinci berbagai masalah dasar manajemen yang dihadapi oleh masyarakat dan kelompok masyarakat pengrajin anyaman eceng godok, baik masalah penerapan fungsi manajemen maupun masalah unsur manajemen. Materi ini menjelaskan tentang Fungsi Manajemen dapat diringkas menjadi fungsi yang pertama adalah Perencanaan (planning). Fungsi ini adalah fungsi manajemen yang harus mampu menjawab $5 \mathrm{~W} 1 \mathrm{H}$ yaitu Apa yang direncanakan (What), Mengapa direncanakan? ( Why), Kapan dilakukan? (When), Dimana dilakukan? (Where) dan Oleh siapa yang melakukan? (Who) dan yang terakhir adalah bagaimana melakukannya?(How). Fungsi kedua manajemen adalah Pengorganisasian (Organizing). Dalam materi ini juga menyajikan berbagai contoh kasus keberhasilan dan kegagalan sektor usaha mikro kecil menengah (UMKM) dalam praktek fungsi dan unsur manajemen. Dengan menyajikan contoh kasus tersebut kelompok sasaran dapat mengambil manfaat praktis dalam tata kelola usaha anyaman eceng gondok. Evaluasi materi ini dilakukan untuk mengukur hasil kemampuan kelompok sasaran dalam memahami dan mempraktekkannya pada kegiatan usaha kelompok, melakukan koreksi dan tindakan perbaikan lebih lanjut. Pada materi ini target yang dicapai adalah $80 \%$ kelompok sasaran mampu memahami dan mempraktekkan manajemen usaha yang efektif dan efisien dalam rangka penguatan manajemen. Adapun sisanya sejumlah $20 \%$ masih membutuhkan tindaklanjut koreksi perbaikan dan pendampingan lanjutan oleh tim pelaksana KKN PPM, pemerintah setempat, mahasiswa dan mitra terkait.

2) Materi Kedua: Standarisasi produksi jenis produksi kerajinan anyaman eceng gondok. Dalam materi ini ditegaskan tentang perlunya penyusunan rencana kegiatan secara ril, penyusunan tahapan rencana secara sistematis, pembagian tugas kelompok untuk penanganan standarisasi produksi, penetapan standarisasi untuk masingmasing produk anyaman eceng gondok, pembahasan dan praktek peraturan dalam penerapan standar. Hal menarik yang terjadi dalam materi ini adalah adanya praktek oleh kelompok sasaran dalam penyusunan standarisasi produksi. Selain itu pula dilakukan kajian terhadap kasus keberhasilan dan kegagalan dalam penerapan standarisasi produksi. Materi ini mampu memberikan pengalam empirik bagi kelompok sasaran dalam standarisasi produksi ragam produk anyaman eceng gondok. Evaluasi terhadap keberhasilan materi dilakukan melalui praktek standarisasi dalam kegiatan produksi, pengamatan langsung dilapangan, pengukuran tingkat keberhasilan, pemberian koreksi dan tindaklanjut perbaikan. Hasilnya menunjukkan $75 \%$ kelompok sasaran mampu mempraktekkan standarisasi produksi anyaman eceng gondok. Sedangkan 25\% sisanya membutuhkan pengulangan dan pendampingan lanjutan dalam penerapannya.

3) Materi Ketiga: Penetapan standarisasi qualitas ragam produk anyaman eceng gondok sesuai kebutuhan pasar. Materi ini menegaskan akan pentingnya mengendepankan kualitas produk anyaman eceng gondok. Kualitas produksi pastilah akan berdampak pada tingkat permintaan produk oleh konsumen. Standarisasi produk anyaman dapat dilakukan secara internal dan eksternal. Secara internal standarisasi ditetapkan oleh kelompok sasaran berdasarkan pengalaman yang 
diperoleh selama ini. Namun demikian disadari juga pentingnya mempertimbangkan ukuran kualitas dari perspektif konsumen. Oleh karena itu tim pelaksana dan kelompok sasaran dalam materi ini juga melaksanakan praktek dalam bentuk survey untuk menjaring bagaimana ukuran kualitas produk anyaman eceng gondok yang diinginkan oleh konsumen. Kombinasi antara faktor internal dan eksternal ini menjadi aspek yang memperkuat kualitas produk. Dampak yang diharapkan tentunya adalah jaminan terhadap kualitas dan peningkatan permintaan pasar. Evaluasi yang terhadap keberhasilan materi dilakukan melalui kemampuan dalam penerapan standar qualitas oleh kelompok sasaran. Evaluasi juga dilakukan melalui pengamatan langsung akan keterpakaian standar kualitas yang telah ditetapkan. Hasilnya menunjukkan bahwa $75 \%$ kelompok sasaran mampu melaksanakan hasil bimbingan teknis sehingga memberikan dampak positif dalam tata kelola standarisasi ragam produksi anyaman eceng gondok. Hasilnya $25 \%$ masih membutuhkan tindaklanjut dalam bentuk evaluasi dan koreksi serta perbaikan tahap implementasinya.

4) Materi Empat: Aspek Manajemen Usaha. Materi ini menegaskan akan pentingnya manajemen usaha yang profesional dalam operasional bisnis. Manajemen sebagai kunci kesuksesan bisnis dilakukan melalui praktek fungsi-fungsi manajemen yang meliputi: perencanaan, pengorganisasian, pelaksanaan, pemasaran dan evaluasi untuk keberlanjutan usaha. Disamping fungsi manajemen dibahas pula dalam materi ini menyangkut unsur-unsur manajemen yang meliputi: manusia (man), bahan (material), mesin (machine), uang (money) dan pasar (market). Pada materi ini juga dibahas tentang pentingnya manajemen strategis. Materi ini sangat penting karena manajemen strategis merupakan suatu rencana yang disusun dan dikelola dengan memperhitungkan berbagai sisi dengan tujuan agar pengaruh rencana memberikan dampak positif bagi organisasi dalam jangka panjang (Fahmi: 2015). Kombinasi antara fungsi manajemen dan unsur manajemen menghasilkan efektifitas dan efisiensi manajemen bisnis yang berkelanjutan. Hasilnya menunjukkan: $80 \%$ kelompok masyarakat sebagai sasaran memahami tentang manajemen bisnis produk anyaman eceng gondok sebagai produk khas dari desa Buhu. Sisanya $20 \%$ dibutuhkan tindaklanjut pendampingan.

5) Materi Keenam: Teori dan Praktek Penyusunan Studi kasus studi kelayakan bisnis. Pada materi ini anggota kelompok sasaran memperoleh pengetahuan dan pengalaman bagaimana menyusun program kerja yang realistis berdasarkan kondisi internal dan kondisi eksternal yang dihadapi oleh kelompok pengrajin pada masa sekarang dan perencanaan bisnis jangka panjang. Pengalaman tersebut meyakinkan anggota kelompok tentang prospek bisnis yang menjanjikan dan pasti untuk produk anyaman eceng gondok yang direncanakan secara realistis, terencana dan sistematis. Dalam materi ini juga dipraktekkan tentang penyusunan rencana bisnis secara periode bulanan dan tahunan. Praktek juga difokuskan pada penyusunan tahapan-tahapan dalam mencapai rencana secara periodik. Kegiatan lainnya adalah simulasi bagaimana menangani permasalahan yang muncul baik secara internal maupun eksternal dan bagaimana pula menghadapi lingkungan bisnis eksternal yang berubah dengan sangat cepat. Hasilnya menunjukkan: $75 \%$ peserta memiliki kemampuan studi kelayakan bisnis dan sisanya $25 \%$ butuh pendampingan lanjutan.

Hasil kegiatan dengan tema pelestarian danau Limboto melalui pemanfaatan eceng gondok sebagai produk kerajinan tangan khas Desa Buhu telah memberikan pengalaman dan penguatan terhadap anggota kelompok pengrajin akan besarnya potensi bisnis anyaman eceng gondok. Disamping itu pula bimbingan teknis telah memberikan bekal pengetahuan manajemen tata kelola usaha beserta penerapannya dalam kegiatan usaha secara berkelanjutan.

\section{KESIMPULAN}

Program KKN-PPM di Desa Buhu Kecamatan Telaga Jaya telah banyak memberikan pengetahuan dan pengalaman empirik bagi tim dosen pelaksana, pemerintah dan utamaya bagi masyarakat pengrajin sebagai kelompok sasaran. Berbagai manfaat tersebut secara rinci dapat diuraikan sebagai berikut:

1) Terwujudnya kesadaran masyarakat pesisir danau limboto, khususnya kelompok pengrajin eceng gondok yang berada di desa Buhu akan pentingnya pemahaman dasar hukum atas perlindungan dan pelestarian danau limboto. Dengan adanya kesadaran tersebut maka berdampak pada partisipasi aktif masyarakat setempat dalam pelestarian danau limboto yang berkelanjutan sebagai sumber penghidupan.

2) Adanya sinergi antara kelompok pengrajin dengan konsumen produk anyaman eceng gondok dalam upaya meningkatkan keberdayaan dan kesejahteraan bersama. Sebagai kelompok sasaran para pengrajin menyadari pentingnya meningkatkan pengetahuan dan keterampilan untuk membangun ekonomi keluarga melalui pemanfaatan sumber daya lingkungan yang bertanggungjawab.

3) Tema KKN PPM di desa Buhu telah membuktikan adanya kontribusi nyata dalam hal tri dharma perguruan tinggi untuk penerapan ilmu pengetahuan dan teknologi yang bermanfaat bagi masyarakat.

Berdasarkan implementasi dan hasil akhir kegiatan maka tim pelaksana mengusulkan beberapa aspek sebagai berikut: 
1) Program KKN-PPM sebaiknya tetap diadakan pada masa yang akan datang karena telah terbukti berkontribusi nyata bagi masyarakat, pemerintah desa, mahasiswa, dosen serta perguruan tinggi.

2) Program KKN-PPM perlu diperluas di berbagai wilayah terpencil untuk mengangkat berbagai potensi desa yang masih terpendam sebagai bentuk komitmen perguruan tinggi dalam program pengabdian kepada masyarakat.

3) Disarankan setelah selesainya kegiatan KKN-PPM dapat dikembangkan dan ditindaklanjuti oleh karang taruna setempat dan pemerintah untuk mempertahankan kelestarian lingkungan danau limboto dan pemberdayaan ekonomi masyarakat setempat yang berkelanjutan.

\section{UCAPAN TERIMAKASIH}

Dengan selesainya seluruh rangkaian kegiatan KKNPPM di desa Buhu Tahun 2018 maka hasil kegiatan ini telah memberikan manfaat bagi kelompok masyarakat khususnya kelompok pengrajin sebagai sasaran. Disamping itu pula manfaat bagi pemerintah Desa, mahasiswa, dosen dan perguruan tinggi. Oleh karena itu pada kesempatan ini kami menyampaikan ucapan terimakasih kepada 1) Direktorat jenderal pengabdian masyarakat Kementerian Ristek dan Dikti Republik Indonesia, 2) Pimpinan dan seluruh staf Lembaga Penelitian dan Pengabdian masyarakat Universitas Negeri Gorontalo, 3) Pemerintah Kabupaten Gorontalo, Kecamatan Telaga Jaya dan pemerintah desa Buhu, 4) Kelompok Ibu-ibu kelompok pengrajin anyaman eceng gondok, 5) Tim pelaksana dan mahasiswa peserta KKN-PPM Tahun 2018. Semoga hasil kegiatan pengabdian ini mampu memberikan manfaat jangka panjang bagi kelompok masyarakat sebagai sasaran dan anggota pengrajin, mitra usaha dan masyarakat sekitarnya.

\section{DAFTAR PUSTAKA}

Fahmi, Irfan, 2015, Manajemen Strategis, Teori dan Aplikasi, Penerbit Alfabeta, Bandung

Mardikanto, T dan Sri Sutarni, T, 2003, Redefinisi dan revitalisasi penyuluhan pertanian, Sukarjo, Solo, Prima Theresia Pressindo

Mas'oed, 1993, Ekonomi Politik Pembangunan dan pemberdayaan masyarakat dalam prospektif, Vol. 5 No. 2

Pemerintah Provinsi Gorontalo Peraturan Daerah Nomor 1 Tahun 2008 pengelolaan danau Limboto

Sumodiningrat, G, 1997, Pembangunan daerah dan pemberdayaan masyarakat, Edisi Kedua, Jakarta, Bina Rena Pariwara

\section{DOKUMENTASI KEGIATAN}

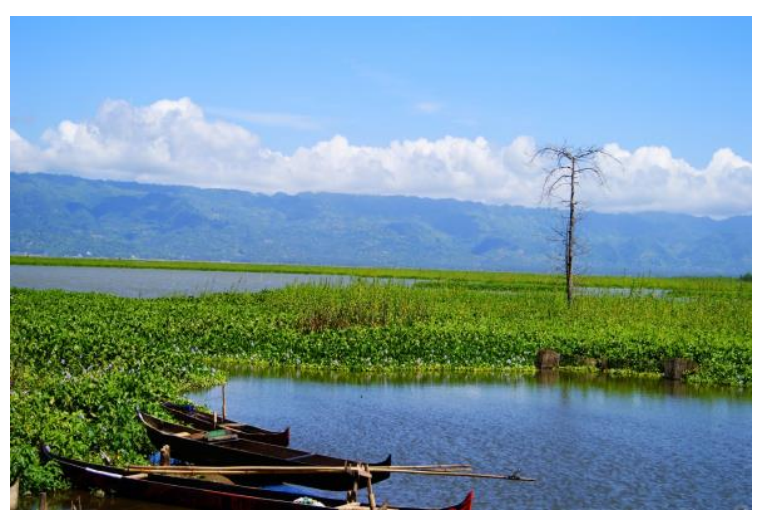

Gambar 1. Eceng gondok di danau Limboto

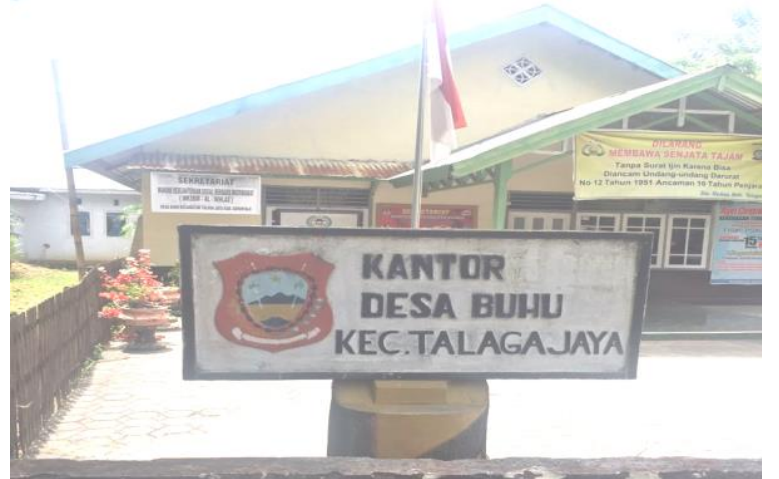

Gambar 2. Kantor Desa Buhu Kab. Gorontalo

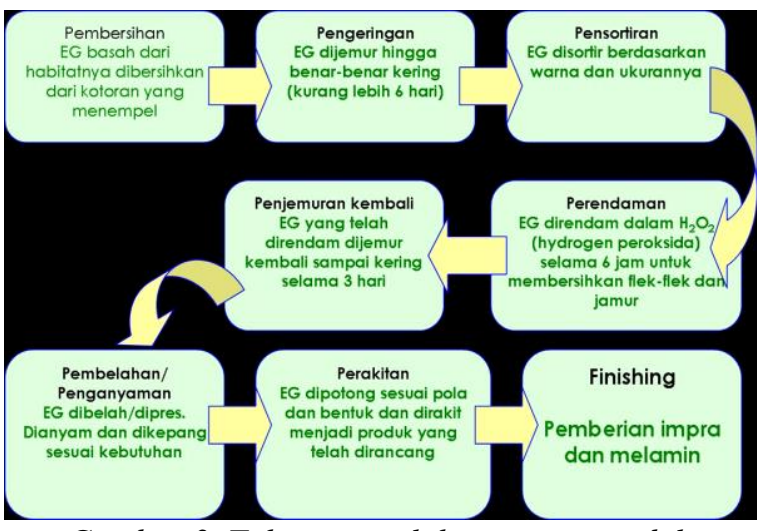

Gambar 3. Tahap pengolahan eceng gondok

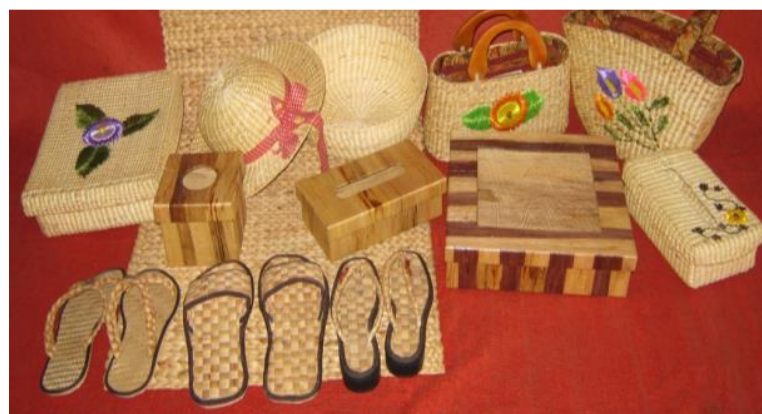

Gambar 4. Hasil Produk anyaman eceng gondok 